\title{
The Role of Management and Monitoring in Achieving Quality Primary Education at Char Area in Bangladesh
}

\author{
Tohidul Islam, Abu Rashel and Na Sang-Gyun* \\ Wonkwang University, South Korea
}

\begin{abstract}
Quality primary education is considered a key component for the achievement of sustainable development goals in a country. The balanced and effective development of a country depends on its educational system where primary education plays a pivotal role. By ensuring quality primary education, Bangladesh may shift its position from least- developed country to medium earning country. This study examines the role of administrative management, monitoringsupervision, community participation and upbringing internal performance to achieve quality primary education in Char area. Mixed methods have been applied to conduct this research work. In this study assistant teachers and head teachers of Char area schools are the respondent. Moreover six educationists have been selected as sample of different public University. Using cluster sampling data has been collected from the respective area and analyzed by ANOVA and regression test with the help of SPSS software. In this study it is found that there is a strong relationship among factors- administrative management, monitoring-supervision and community participation for ensuring quality primary education at Char area in Bangladesh. It is strongly suggested that the government can take suitable steps to involve conscious and prudent personalities of the community for ensuring effective administration and supervision for achieving quality primary education.
\end{abstract}

Keywords: Quality Primary Education, Management, Monitoringsupervision, Community Participation and Bangladesh.

\section{Introduction}

Quality primary education is the key influential constituent for sustainable progress and it strengthens human resources to develop any nation (Shaleh, 2018). Bangladesh, a developing country, in south Asian region has been financed adequate amount of capital in primary education sector to ensure universal primary education as basic need for every child of the country. Article 17 in the

*Corresponding author, Email: $\underline{\text { nsghy@wku.ac.kr }}$ 
constitution of Bangladesh emphasizes for universal and compulsory primary education so that every citizen can literate at free of cost. The constitutional responsibility of this state is to create equal and impartial opportunities ensuring easy and smooth accessibility of every pupil to elementary school irrespective of ethnic class, unfavourable environments, mental and physical restrain and other challenges like religious minority and linguistic variation or even the regional gap. The general perception of the government is that primary education plays positive role in the socio-cultural changes, national growth and long-term sustainable development. Bangladesh Government took the massive challenge of launching Universal Primary Education (UPE) in 1991. Consequently at present the gross enrolment is more than hundred and the net enrolment rate is calculated as $98 \%$ where passing rate is almost $98.45 \%$ (BASPR, 2017). This is the incredible improvement regarding to achieving the aims of UPE but its lags behind in ensuring quality primary education (Ahmed et al., 2005; Choudhury, et al., 2001; Khan, \& Ahmed, 2007; Latif, 2004; Majumder, 2006; Nath \& Chowdhury, 2009). Moreover the students of char areas are lagging behind in terms of quality and competency in comparison to other mainland primary school students.

Char area is significantly different from the mainland of the country. Generally, the groundwater formed by the flow of the river or the sedimentation in the estuary is known as char. The land areas of this study are surrounded by the river and the remote villages are scattered from mainland and urban area of Bangladesh. It is a river profuse country where some places are remote, backward and far away from urban, semi-urban and even some advanced rural areas. The char areas are affected in frequent natural disasters, specially the communication system of these areas become shaggier during and after the disaster. As a result regular correspondence is interrupted. But proper monitoring and regular supervision are indispensable for ensuring standard teaching. For these above reasons the pupils of school of char area (SCA) fail to acquire proper teachinglearning practices. Management and monitoring are considered as the vital factors to maintain quality education in school. The goal of primary education would not be achieved without effective monitoring-supervision and management. Nonetheless management - supervision are most crucial factor to achieve the entire excellence elementary education. Ushadevi ( 2001) claims that supervision inspire to teachers about healthy teaching-learning procedure and making them aware of educational plans, programs and policies. Management, monitoringsupervision are key factors to concentrate the teachers for effective teachinglearning practice. The authority should restructure school management system for satisfactory quality in education. The concentration of this is to explore how monitoring and management would be deployed to confirm quality education in SCA in Bangladesh. Monitoring and supervision are considered as instruments for quality assurance in this study in terms of the universal basic education program at char area in Bangladesh. Specially, it has been mentioned the necessity of management and monitoring of the responsible supervision agencies. 


\section{Hypothesis of this Research}

The following hypothesis are framed and tested in this study:

H1: There would be significant relationship between management and quality education in primary schools of char area.

$\mathrm{H}$ 2: There would be significant association between monitoring-supervision of teaching-learning processes by the authority and standard education in primary level schools of char area.

H3: There would be significant relationship between Community participation and quality education in primary schools of char area.

H4: There would be significant association between internal environment of school and quality education in primary schools of char area.

\section{Review of Related Literature}

\subsection{Quality of Education}

The two basic philosophies of quality education which are used to define quality primary education are: 'intellectual advancement' of the pupils and the role of education in stimulating morals and outlook in the midst of conscious citizens and for nurturing resourceful improvement (UNESCO, 2004). In fact, cognitive progress is the research of learner neurological and psychosomatic growth. Specifically, cognitive improvement is judged based on the level of conception, sensitivity, information processing and linguistic development as an indicator of intelligence advancement. Usually it is acknowledged that cognitive upgrading and growths frequently happened with age as anthropological consciousness and indulgent of the world increases from infancy to childhood and then again in adolescence. Human values and attitudes are achieved through acquiring knowledge on a specific process where inputs, process, outputs and outcomes are the proper and recognized procedure to achieve the knowledge, skill and attitudes in formal system education (Ahmed, et al., 2005). Sometimes to hold quality this procedure is not being followed systematically. The quality of education means some specific components' proper handling these are inputs, processes, outputs and outcomes. In the perspective of education inputs are included sufficient teachers, trained teachers and purposeful textbook. Processes indicate duration of schooling time and actively teaching learning procedure in the classroom. Outputs will be test scores and graduation rate of the pupils in the specific academic session. Moreover outcomes become students' performance in their practical life (Chapman, D. W. et al., 2002). Furthermore, the quality of education is able to gain the definite aims and objectives of a country. There is a comprehensive impact on learner understanding, approaches, values and conduct if the children will be performed proper schooling (Adams, 1998). It is very challenging to identify the definition of quality in education. There is difference opinion about quality of education. So somebody thinks quality means supremacy, someone considers quality means efficiency, competence and fairness, and someone articulates quality assists the purpose and harmonized with desires and goals of any program (World Bank, 1994). There are six component of quality education in the research of the UNICEF. These component are students, educators, educational atmosphere, contents, processes, and outcomes which has 
been founded to reserve the children rights which give its safety, development and participation in any activities (UNICEF, 2000).

There is no particular and strong definition of quality education in the perspective of Bangladesh in any policy papers like education policy -2010, primary curriculum of National Curriculum and Textbook Board, Bangladesh (NCTB) and national plan of action on education for all. Nonetheless, Primary Education Development Project (PEDP-II) mentioned that the official papers of quality upgrading schemes and action plan of the government revealed a good number of activities defining quality of education at primary stage. So these elements are closely related in education that is trained teacher, enhancement of teaching learning approach, sufficient infrastructure, creative school management committee (SMC), educational monitoring-supervision of schools, community participation and local level planning (MoPME, 2003; UNICEF, 2004). Since elementary education is beginning stage of the learner's life the above elements are considered very seriously. UNESCO (2004) define quality of education that the sum of a few effective element which are strong ethical teacher, academic good result, parental care learners, community participation, sufficient infrastructure, the use of latest technology, effective leadership, present demanded curriculum, educational aids and resources

\section{Antecedents of Education Quality}

\subsection{Management and Quality Education in Primary Schools}

The staffs of an institution make excellent and adequate performance whether proper management is conducted by the authority. To improve quality of education school management system is vital factor to encourage reciprocal appreciatively between the students and teachers. Appropriate step and measurement is being taken to increase the interest of guardians concerning about their children' education and schools through the formation of sincere-active Parents Teachers Association (PTA) ((NEP, 2010). Accurate management plays direct role in effective teaching- learning process at classroom of primary school in rural areas. By the observation of teaching style, teachers are to become very conscious to teach the learners in classroom effectively (Sultana, 2019). Usually primary administrations have responsibility in four areas that can contribute to achieve quality education at primary level: (i) supervision and management in school (ii) arrange communications between school and education ministry (iii) local community relationships in school specially acquiring new instructional policies of parental backing; and (iv) pedagogical observation, e.g., teachinglearning direction by head of institute (Chapman, 2002). Classroom management is an actual teaching outline focusing on interactions between teachers and students. The biological, psychological, cultural and behavioural processes of teacher-student associations are grounded in classroom interaction domains through the effective management system (Solheim, 2019).

Many scholars have researched South Asian educational issues where they identified various types of problems in the education system in South Asian countries. These are insufficient, retrograde textbooks and curriculum, 
inappropriate trained teacher, lack of supervision, insufficient facility of the teachers and weak and insignificant management in school. Defective assessment methods and frequently changing education policy are creating complication in education of developing countries. Potential management conditions for teachinglearning are essential to improve quality primary education (Adams, 2002; Heneveld, 1994; Horn, 1992). Heneveld et al., (1994) also explained current trends towards the decentralized management of education, greater attention to better classroom teaching techniques, and national assessments that provide feedback directly to schools. Students' facilities teaching equipment, contemporary curriculum, teachers' behaviour, and systematic management practices are relatively independent of each other in their impact on student performance.

\subsection{Monitoring-supervision and Quality Primary Education}

Academic supervision is one of the core functions for improving academic practices at implementation level of any field. In particular, the academic activities of a school as well another activity largely depend on the proper academic supervision by the experts. Supervision is a key function to advise, assist and support school heads and others teachers. Monitoring is a specific procedure where inputs, process and outputs are subsistent in educational system. It is internal management which formulates applied action to reach the expected outcomes (UNESCO, 2007). Ajayi (1985) exposed that regulation includes the inspiration of professional development which help further progress and improvement of the teaching- understanding situation in the school. Raudenbush and Bhumirat (1991) have shown that there is strong relationship between the concentration of internal supervision by the head of institute in primary school and the academic achievement of students of those respective teachers. The researchers also added that appropriate training of the teachers contribute high quality of primary education. Head-teachers play a very strategic position in education by playing the combined roles of being managers, directors, organizers, coordinators, communicators, facilitators and stimulators at the same time. These make them very important in realizing educational and learning success and, on a broader scale, in determining the success of nationbuilding (Rohman, 2019). Fuller \& Clarke (1994) investigated that the pragmatic consequence of school visit functions indicate that routine visits and monitoring of schools and teachers helps to detect deficiencies in the school system and thereby help teachers to make better performance.

Hossain (2019) reveals that supervisor as one who accelerates, stimulates, supports, and encourages the teachers to try new things. Researcher also found that monitoring-supervision contributed to reach expected quality education. The school inspector plays different kind of role to facilitate in the context of several national level interventions that are currently in operation in primary schools across the country in the direction of achieving universal primary education of good quality. The study essentially looks at the apparently major activity performed by the school inspectors in terms of school visits and tries to find out in what extent activities play an empowering role to expand the performance of the school. The researchers also focuses on the result of monitoring functions of the school inspectors in the form of school visit, which is 
one of the crucial modules of the external supervision support service that succeeds in the Indian educational system (Ushadev, 2001). Organizational and administrative theories justify the need for an effective monitoring and inspection system for optimal performance of a system. Similarly, evidence is also available that monitoring and inspection system play positive role to maintain and improve the quality of services in educational institutions (Blackie, 1970; Bolam, et.al, 1986; Dodd, 1968; ; Lyons,1997; Lyons \& Pritchard, 1976; Maclaine, 1973; World Bank, 1999). Inadequacies of systematic monitoring and inspection by school administration are responsible for continuing poor quality of primary education (Marlaine et al., 1991)

\subsection{Community Participation and Standard Elementary Education}

Community and parental participation are resilient in schools with high communal teacher ability. When community members involve in cooperative action in education sector, their mutual capability is able to improve the quality of education in elementary level (Blatti, Clinton \& Graham, 2019). The management committees should be empowered to advance in the development of school activities. As a result community participation will be ensured to require the aims and objectives of education. So it consists of elected members of local area, some ex-official personal and teacher of respected school. According to the regulation they are able to perform their accountability to confirm quality education in the respective school (NEP, 2010). Nevertheless some new important element may be including stimulating leadership who would try to connect the local community. Even that community can generate the innovative tasks, accepting and consuming information to progress the quality education. In a char area school managing committee (SMCs) are not conscious of their roles and accountabilities because they have not received any training on their duties in respect to their accountability and duties in primary schools. Most of the SMCs do not play actual roles to maintain supervision and monitoring of school activities (Mamun, 2014). Based on the above review, researcher hypothesizes:

\subsection{Internal Environment and Quality Education in Primary Schools}

School environments have a strong effect on educational quality because employees want a relaxed working environment during teaching-learning session in the school (Ikoya et al., 2008). Congenial and joyful learning environment, at every primary school is essential to encourage suitable, physical and mental improvement of the learners. Practical learning atmosphere of school will be made gorgeous and enjoyable so that every pupil could take pleasure in the learning period at school. Moreover the authority provides adequate facilities for the students such as sports competition, cultural activities, warm interaction, a clean smooth atmosphere of the school, caring- sympathetic manners between teachers and learners (NEP, 2010). Ahamad et al. (2006) educational inputs include economic measures and infrastructure measures. Financial measures are summarized by instructive disbursement per students. Physical measures mean classroom facilities, sports materials, library and other educational aids. It is also said that internal good environment is essential to hold learners' attention in studies. Ibrahim et al. (2011) mentions that the state should offer quality teaching, research in primary education sector and community 
service to its students. It also discusses that rural non-government school does not have the necessary physical facilities and qualified teachers to teach properly. The study also recommends that all type of school in rural and urban can be gotten equal physical facilities, and innovative qualified teachers for better teaching cooperation. Good learning environment facilitates to ensure quality teachinglearning. It is a combination of physical facilities of school and classroom organization too. It can be said that physical facilities always contribute supplementary role to ensure quality education (Lokman, 2017).

\section{Objective of the study}

The purpose of this study is to determinate the factors that influence in achieving quality primary education at char areas in Bangladesh. More specifically, the study aimed to attain the following objectives:

(i) To analyse the administrative management that effect on quality education.

(ii) To investigate the role of monitoring-supervision in achieving quality primary education at char area schools.

(iii) To identify community participation that contributes to achieve effective teaching learning practice in char areas school.

(iv) To determinate the consequence of internal environment in achieving quality primary education.

\section{Conceptual Framework}

Perspectives of monitoring and management are to achieve the targets and goals ensuring quality of primary education (QPE) in SCA comprises three horizontals: governing level, implementation level and outcome level. The governing level includes management, monitoring, supervision, community participation and internal environment. Implementing level is teaching- learning practice in the classroom. The result of the outcomes is quality of education in Char area schools.

The conceptual framework can be schematically presented as the following manner:

\section{Governing Level \\ Implementation Level Outcomes Level}

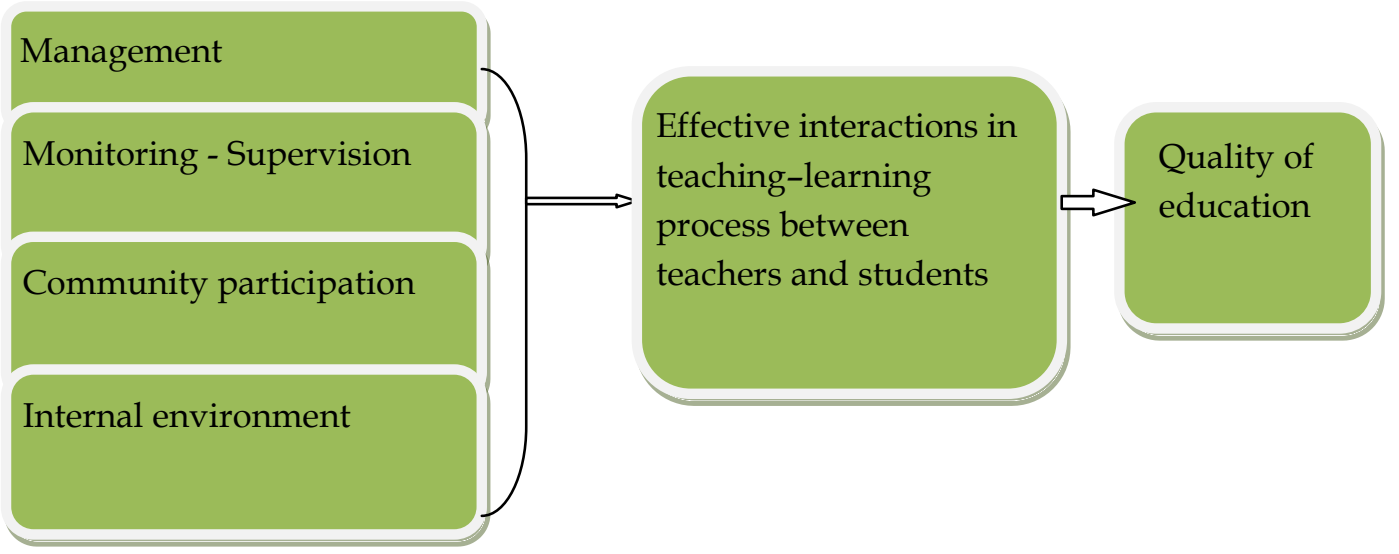

Figure 1. Conceptual Framework of this Research 


\section{Methodology of the Study}

Mixed method strategies have been used in this study comprising qualitative and quantitative components. Data have been collected from primary sources as well as secondary documents. To realize the objectives of this study, researchers have made textual analysis, in depth interview and the questionnaire survey. This study uses five point Likert scales scoring methods which gives $5-1$ point for the options from strongly agree to strongly disagree. Using these methods researchers has collected data from the selected areas. To justify the research objectives, qualitative and quantitative results have been integrated and synthesized through cross sectional description.

\subsection{Population and Sampling Process}

The population of this study consists of assistant teachers, head-teachers and educationists. The total sample size of this study is 289. Sample is selected using cluster sampling.

Table 1: Structure of sampling distribution

\begin{tabular}{|c|c|c|c|c|}
\hline Study area & $\begin{array}{c}\text { Category of } \\
\text { respondent }\end{array}$ & $\begin{array}{c}\text { Data collection } \\
\text { tools }\end{array}$ & $\begin{array}{c}\text { Sampling } \\
\text { techniques }\end{array}$ & $\begin{array}{c}\text { Number of } \\
\text { respondents }\end{array}$ \\
\hline \multirow{3}{*}{ Bangladesh } & $\begin{array}{c}\text { Assistant } \\
\text { Teacher }\end{array}$ & $\begin{array}{c}\text { Questionnaire } \\
\text { survey }\end{array}$ & Cluster sampling & 269 \\
\cline { 2 - 5 } & Head Teacher & Chick list & $\begin{array}{c}\text { Purposive } \\
\text { sampling }\end{array}$ & 14 \\
\cline { 2 - 5 } & Educationist & $\begin{array}{c}\text { In-depth } \\
\text { interviews }\end{array}$ & $\begin{array}{c}\text { Purposive } \\
\text { sampling }\end{array}$ & 06 \\
\hline & & & Total $=$ & 289 \\
\hline
\end{tabular}

\subsection{Data Analysis Techniques}

All data have been processed and analysed according to the hypothesis of the study. Quantitative data have been analysed using SPSS software where ANOVA and regression analysis adopted. On the other hand qualitative data have been interpreted through textual analysis.

\subsection{Interview Process}

In a qualitative research, Interview is one of the crucial data collection methods. Using unstructured schedule, researchers conduct interview from December/2017 to January/2018 with the help of several governmental officials, some expert who has vast knowledge in quality education and six educationists from Bangladesh.

\subsection{Questionnaire}

By applying survey method the researchers have collected the data from char area schools during December/2017 to January/2018 using 5 points Likert scale i.e, strongly disagree to strongly agree. 


\section{The Results of Data Analysis}

\subsection{Results of Interviews: Administrative Management-Monitoring for Primary Education}

District Primary Education Administration \{District primary education officer (DPEO), Upazila education officer (UEO) and Assistant upazila education officer (AUEO)\} play an important role to improve quality education in SCA. Monitoring and management activities are taken by district primary administration and especially AUEO performs the inspection activities in the field level. The activities include regular school visit; checking attendance of teachers; checking teacher's lesson plan; annual work plan; class observation; checking students learning outcome and checking for maintenance of essential record. The above activities of AUEO are very crucial for quality education in char area. But they do not monitor the school properly on the regular basis due to communication constraints, negligence, lack of responsibility, and relaxation for submitting explanation to the authority. Most of the Head-teachers claim that AUEO comes to visit in the school one or two times in an academic year. Therefore the reality they neither observe the classroom teaching learning process nor do they offer on the spot guidance to the teacher for improvement of teaching-learning process. They just maintain the register and conduct a sample test of the student capability.

A majority number of key informants point out that AUEO and UEO visit the schools which are situated nearest from Upazila sadar. But they do not monitor the remote area especially in SCA. They also add that about $60 \%$ of the Char area schools have no head teacher even there is no sufficient assistant teacher in those schools. Most of the key informants claim that monitoring function of AUEO is not highly systemized in SCA. Moreover, they do not maintain sub-cluster training properly in those of Char areas schools. They also state that the AUEO does not have sufficient orientation and training which can enable them to perceive roles with much more professionalism. UEO visits the SCA for once or twice in its tenure in the respective area and even some UEO does not make a single visit in SCA in this tenure. The visit of the DPEO or ADPEO in SCA is similar to the visit of an alien in SCA. Some key informants states that monitoring and management occurs at school by the various levels of district primary administration officers, head teacher and SMC members but there is no combination of their activities to confirm quality of education in SCA.

Effective and inclusive SMC is indispensable part to improve primary education sector. But it is not observe SMC and community involvement with Char area school to improve quality education. Even SMC are not aware of their role and responsibilities. Most of the SMC members have not received any training on their activities from Directorate of Primary Education (DPE). The SMC members of the char area school do not or rarely visit to observe the teaching learning process and teachers' attendance. Even larger number of the SMC members do not participate the meeting of the school. Finally DPE does not take necessary step to involve the SMC and community participation. Some key informant states that observation of the teachers' attendance in school is very important for quality education but the posted teacher of char area school do not carry out their duty properly. Most of the teachers attend in the school two or three days in a week and even that the 
teachers usually do not attend in time rather the lately and leave the school earlier. It has also been found that some teacher does not come in the school at all. Rather those teachers appoint some nominal educated people as the part time teacher and pay some money. There are negative impacts on learning outcome in SCA due to irregularities and untimely presence of teachers at schools and other anomalies. Nevertheless DPEO does not take proper steps to prevent these negligence and irregularities.

\subsection{Results of Questionnaire Analysis}

This section provides the results of the estimations towards attaining the objectives set for this study. The results are drawn from the questionnaire survey of primary assistant teachers in Char areas. After that results from One-way ANOVA are presented. Finally, the estimation results of the multiple regression model showing the influence of management, monitoring-supervision and community participation factor in achieving quality primary education.

\subsection{Reliability of data}

Reliability is the degree of consistency with which the instrument measures an attribute (polit \& Hungler, 1999). The initial reliability of the items has been verified by computing the Cronbach's alpha. The Cronbach's alpha suggests that a minimum alpha of .6 is sufficed for the early stage of research (Nunnally, 1978). The Cronbach's alpha estimated for all of the variables is .760, .732, .764 and .575 table 2) therefore deemed to have adequate reliability.

Table 2: Validity testing

\begin{tabular}{lcc}
\hline Name of factors & Cronbach's Alpha & Composite Reliability \\
\hline Administrative management & .760 & .850 \\
\hline Monitoring - supervision & .732 & .841 \\
Community participation, & .764 & .893 \\
Internal environment & .575 & .784 \\
\hline
\end{tabular}

Table 3: the Status of the Effect of Independent Variable towards Quality Education in SCA

\begin{tabular}{llllll}
\hline Model & $\begin{array}{l}\text { Sum of } \\
\text { Squares }\end{array}$ & Df & $\begin{array}{l}\text { Mean } \\
\text { Square }\end{array}$ & F & P-value \\
\hline Regression & 86653.426 & 4 & 21663.357 & 106.652 & 0.000 \\
Residual & 53624.135 & 264 & 203.122 & & \\
Total & 140277.561 & 268 & & & \\
\hline
\end{tabular}

Dependent Variable: Quality primary education.

Predictors :( Constant), Management, Monitoring-supervision, Community Participation, Internal Environment 
According to the ANOVA or F Test, the calculated value of $F$ test is 106.652 and p-value is 0.000 which is less than 0.05 . So the test is statistically highly significant. The regression model can be used to predict acquiring quality primary education based on the management, monitoring-supervision, community participation and internal environment, respectively.

Table 4: Multiple regression analysis of M, MS, CP and IE towards achieving quality education

\begin{tabular}{|cccccc|}
\hline Model & \multicolumn{2}{l}{$\begin{array}{l}\text { Unstandardized } \\
\text { Coefficients }\end{array}$} & $\begin{array}{l}\text { Standardized } \\
\text { Coefficients }\end{array}$ & $\mathrm{T}$ & P- value \\
\cline { 2 - 4 } & $\mathrm{B}$ & $\begin{array}{c}\text { Std. } \\
\text { Error }\end{array}$ & Beta & & \\
\hline Constant & 0.287 & 5.797 & 0.302 & 0.049 & 0.961 \\
M & 0.284 & 0.062 & 0.250 & 4.571 & 0.000 \\
MS & 0.314 & 0.051 & 0.315 & 6.098 & 0.000 \\
CP & 0.452 & 0.045 & 0.423 & 9.979 & 0.000 \\
IE & -0.014 & 0.249 & -0.002 & -0.057 & 0.954 \\
\hline
\end{tabular}

Note: M: Management; MS: Monitoring - supervision; CP: Community participation, and IE, Internal environment.

Table 4 shows that there is positive relationship between management, monitoring-supervision, community participation and quality of primary education. M, MS, and CP (because, p-values 0 these factors are less than 0.05) are the significant factors to improve quality of primary education. $\mathrm{H} 1$ state that, there would be direct relationship between management and quality education in primary schools of char area. Hair et al. (2010) present that in case of the path coefficient value minimum 0.15 and above, the result can be considered as statistically significant. In this aspect, -regression model, reveals that the values of coefficient 'Pragmatism Administrative Management' of char area are 0.250, 0.284 standardised and unstandardized coefficients respectively. So quality of primary education at char area is significantly affected by the management. Moreover $\mathrm{p}$ value is 0.000 which is less than 0.05. Therefore this study accepts Hypothesis 1 .

Quality of education at char area is influenced by the monitoring- supervision. The result is to be considered as statistically significant where the path of coefficient value is between minimum 0.15 and above (Hair et al., 2010). In this aspect, regression model, exposes that the values of coefficient pragmatism monitoring-supervision of char area are $0.315,0.314$ standardised and unstandardized coefficients respectively. So achieving quality of primary education at char area is significantly affected by the monitoring-supervision. Moreover p-value is 0.000 which is less than 0.05 . Therefore, the present study accepts the Hypothesis 2. 
$\mathrm{H} 3$ presents that, achieving quality of primary education at char is influenced by the community participation. Hair et al. (2010), reveal that the path coefficient value should be minimum 0.15 and above to be considered as statistically significant. In this aspect, regression model, Table 4 depicts that the values of coefficient pragmatism community participation of char area schools are 0.423 , 0.452 standardised and unstandardized coefficients respectively. So achieving quality of primary education at char area is significantly affected by the community participation. Moreover p-value is 0.000 which is less than 0.05 . Therefore, this research accepts the Hypothesis 3.

This study presents that quality of primary education at char area school does not influenced by the internal environment. Hair et al. (2010), utter that the path coefficient value should be minimum 0.15 and above to be considered as statistically significant. In this aspect, regression model, exposes that the values of coefficient Pragmatism internal environment of char area are $-0.002,-0.014$ standardised and unstandardized coefficients respectively. So achieving quality education at char area is not affected by the internal environment. Moreover $\mathrm{p}$ value is 0.954 which is greater than 0.05 . Therefore, this research has not accepted the Hypothesis 4.

Table 5: Effect of Management, Monitoring-supervision and Community Participation of School on Quality Primary Education

\begin{tabular}{|ccccc|}
\hline Model & $\mathrm{R}$ & R Square & $\begin{array}{c}\text { Adjusted } \mathrm{R} \\
\text { Square }\end{array}$ & $\begin{array}{l}\text { Std. Error of the } \\
\text { Estimate }\end{array}$ \\
\hline 1 & 0.786 & 0.618 & 0.612 & 14.252 \\
\hline
\end{tabular}

Table 5 indicates that the value of coefficients of determination $\left(R^{2}\right)$ is 0.618 that means $61.8 \%$ variance in quality education is predictable from Management, Monitoring-supervision, and Community participation. It can be said that quality of primary education influenced $38.2 \%$ by the other factors. So finally, we conclude that if we increase the management, Monitoring-supervision of the teaching-learning process, and community participation, then the quality of primary education must be improved.

\section{Summary of Result}

The future of Bangladesh depends on the socio-political performance and behaviour of her mass people. The root of self-education, job oriented training and advance schooling are deeply engrained in its worth primary education. In this aspect, quality of primary education is in the centre of development for human resource. To ensure quality primary education at char area, regular school visit; checking attendance of teachers; checking teacher's lesson plan; annual work plan; class observation; checking students learning outcome are very indispensible matters. But these activities are not properly maintained by the relevant authority. Above the activities should be performed collectively by the district primary administration, school management committee and head master. 
The study result shows that administrative management positive impact on quality primary education $(\beta=0.250, P<0.05)$. It is proved that there is significant association between the quality primary education and administrative management. However monitoring-supervision has significantly positive impact on QPE $(\beta=0.315, \mathrm{P}<0.05)$, there is positive co-relation between monitoringsupervision and quality primary education in char area schools. Community participation has positive effect on quality primary education $(\beta=0.423, \mathrm{P}<0.05)$. End of the conclusion it can be said if we increase 0.01 unit of the management, Monitoring-supervision of the teaching-learning process, and community participation, the quality of primary education must be improved 0.01 units. So it is statistically ascertained that quality of primary education is influenced by administrative management, monitoring-supervision and community participation. The findings suggest that administrative management, monitoringsupervision and community participation are crucial factors to improve education quality at char area schools. The regression result also indicates that management, monitoring-supervision and community participation play significant role to ensure quality primary education at char area schools in Bangladesh.

\section{Limitations and Further Research Scope}

As it is mentioned earlier this research is carried out on char area of Bangladesh which is a very small segment of total population Bangladesh. In broader perspective small sample makes tougher a research to generalize its findings. However there is an essential issue in this study where enough time is needed to collect tangible and precise data from the respective field. But its budget constrain does not allow long time for survey and in-depth interview. Management, supervision-monitoring, community participation and internal environment are mostly fundamentals factors of quality education. In this situation, this research reveals these factors at char area primary school in Bangladesh are closely related to improve education in broader perspective. Thus there are more scope to handle the research where could be discussed the mainland primary level school educational status. Then there would be further visible comparisons between urban and char areas' primary school status and it would be more effective and accurate findings regarding the impact of management and monitoring in ensuring and strengthening quality primary education.

\section{Policy Implications}

The following policy implications can be formulated on the basis of the findings of this study:

Firstly, special concentration should be given to undertake and extend management capacities as the capabilities of different authoritative bodies can be enriched which improve total circumstances of SCA.

Secondly, pragmatic and result-oriented considerations should be taken to develop responsive behaviour of teachers attracting the students in SCA. Commensurate programs should be taken to train up the teachers for making the 
teaching methods cheerful, pleasant and students' friendly. A reliable, attractive and congenial atmosphere should be provided to improve the quality education in these remote area schools.

Thirdly, attractive attempts should be taken for community participation in school-activities, to reformulate the SMC comprising all stake-holders, ex-officio members, conscious local personalities and others elected through need-based considerations.

Fourthly, co-curricular and extra-curricular activities including sufficient facilities for games, sports, cultural activities, outing and visit to renowned places, warm interactions between teachers and students should be to make the school attractive and joyful.

Fifthly, special and need-based training for the Head-teachers should be arranged so that they can perform their duties with prudent and skill as the fundamental responsibility of supervision within schools rests with them.

Lastly, all the four tiers of government, District primary education officer, UEO, AUEO and School Managing Committee should supervise to improve the teaching-learning procedure of char area primary school. District primary administration has to perform regular basis visit in terms of checking of teachinglearning process and class observation. Concern ministry should be trained up the district primary administration about pedagogical and content knowledge so that they can guide and provide necessary instructions to the teacher on the spot.

\section{Conclusion}

The quality of primary education depends on standard teachers, enthusiastic students, and congenial environment. But in most cases the char area of Bangladesh lacks these conditions. Without taking proper care, pragmatic initiatives, and target-oriented guidelines for primary education in char area sustainable education goals of the country cannot be ensured. Proper monitoring, regular supervision and effective management (MMS) can assist to ensure quality primary education in char area. This study has shown that there is positive correlation between MMS and QPE in char area. The government and educational authority of the country can take initiatives to involve conscious and prudent personalities of the community and ensure administrative supervision on the regular basis for monitoring and management. The authority can take steps to increase logistic supports for quality teachers to teach in SCA and financial and recreational facilities for students to study school taking part in the teachinglearning process. Every communities of the country will try to succeed the strategies of education policy so that sustainable development goals of nation are attained through the education. 


\section{Reference}

Adams, D. K. (2002). Education and national development: Priorities, policies, and planning. Manila Philippine: Asian Development Bank.

Ahamad, Z., \& Mirza, M.S. (2006). The financing of Privately-Managed School in the Panjab. Retrieved on 20thJune, 2015 from. http:/ unesdoc.unesco.org/ images/ 0007/ 00015 / 071513 eo.pdf.

Ahmed, M., Nurul, I. K., Romij, A. \& Saleh, A. K. (2007). Access to education in Bangladesh: Country analytic review of primary and secondary education. Dhaka: BRAC University, Institute of Educational Development (BU-IED).

Ajayi, K.\&Sokan(Eds).(1997).Instructional Supervision and Practices in Primary schools: Effec tive Managementof Primary Education. AdeoseT.C.S: Bodija.

Al Mamun, M. A. (2014). Assessing the effectiveness of school management committees (SMCs) in improving governance of primary schools in Bangladesh: A case study of selective SMCs at Gouripur Upazila in Mymensingh district (Unpublished master's thesis). BRAC University: Dhaka.

Bhuiyan, A. K. M. Zakir Hossain (2019). Supervision and primary education Quality Assurance Strategies in Rural Areas School: Implication for National Educational Policy of Bangladesh -2010. Journal of National Academy for education Management, Dhaka. 5(2), 49-63.

Blatti, T., Clinton, J., \& Graham, Lorraine (2019). Exploring Collective Teacher Efficacy in an International School in Shanghai. International Journal of Learning, Teaching and Educational Research, 18(6), 214-235. https://doi.org/10.26803/ijlter.18.6.13

Bolam R. (1986). School Inspectors and Advisers' The International Encyclopedia of Education. Torsten Husen \& T N Postelthwaite, (eds). Paris: Pergamon Press.

Chapman, D. W. (2002). Management and efficiency in education: Goals and strategies. Hong Kong: Asian Development Bank.

Chapman, D. W., \& Adams, D. K. (2002). The quality of education: Dimensions and strategies. Hong Kong: Asian Development Bank.

Dodd, W. A. (1968). Primary School Inspection in New Countries. OUP: Oxford.

Education Watch Project (Bangladesh), Ahmed, M., Hossain, M. A., \& Nath, S. R. (2005). Quality with Equity: the primary education agenda. Campaign for Popular Education, Bangladesh: Bangladesh.

Fuller, B., \& Clarke, P. (1994). Raising school effects while ignoring culture? Local conditions and the influence of classroom tools, rules, and pedagogy. Review of educational research, 64(1), 119-157.

Hair, J. F., Anderson, R. E., Babin, B. J., Black, W. C., \& Tatham, R. L. (2006). Multivariate data analysis 6th Edition. Pearson Prentice Hall. New Jersey. humans: Critique and reformulation. Journal of Abnormal Psychology, 87, 49-74.

Heneveld, W. (1994). Planning and Monitoring the Quality of Primary Education in SubSaharan Africa. (AFTHR Technical Note No. 14). Washington, DC: World Bank, Human Resources and Poverty Division.

Horn, R. (1992). The Fundamental Quality Level Indicator System for Primary School. (draft memorandum). Washington: USAID.

Hussain, Dr. Md. Lokman (2017). Quality education at elementary school level: Bangladesh perspective. Journal of National Academy for education Management, Dhaka. 3 (1), 83-96.

Ikoya, P. O., \& Onoyase, D. (2008). Universal basic education in Nigeria: Availability of schools' infrastructure for effective program implementation. Educational Studies, 34(1), 11-24.

Latif, S. (2005). Improvements in the quality of primary education in Bangladesh 19902002. (EFA Global Monitoring Report). Paris: UNESCO. 
Lockheed, M. E., \& Verspoor, A. M. (1991). Improving primary education in developing countries. Oxford University Press for World Bank.

Lyons, R. F., \& Pritchard, M. W. (1976). Primary School Inspection: A Supporting Service for Education. Paris: IIEP

Maclaine, A. G. (1973). An Evaluation of the System of Inspection in Australian State Schools. Journal of Educational Administration, 11(1), 22-32.

Ministry of Education (2004). National Education Commission Report -2003. Dhaka: Ministry of Education, the Government of the People's Republic of Bangladesh

MOPME. (2003). Education for All: National Plan of Action II. Dhaka: Ministry of Education, the Government of the People's Republic of Bangladesh.

MOPME. (2007). Final assessment report: national assessment of pupils of grades 3 and 5. Dhaka: Directorate of Primary Education, the Government of the People's Republic of Bangladesh.

Mundy, K. (2006). Education for all and the new development compact. Education and social justice, 13-38.

Nath, S. R., \& Chowdhury, A. M. R. (2001). A Question of Quality: State of primary education in Bangladesh: Achievement of Competencies. Dhaka: University Press Limited and Campaign for Popular Education.

Nath, S. R., \& Chowdhury, A. R. (2009). State of primary education in Bangladesh: Progress made, challenges remained. Dhaka: Campaign for Popular Education, Bangladesh.

Ministry of Education. (2010). National Education Policy. Dhaka: Ministry of Education, Government of the People's Republic of Bangladesh.

Nunnally, J.C. (1978). Psychometric theory (2nd ed.). New York: McGraw-Hill.

Polit, D. F., \& Hungler, B. P. (1999). Nursing research: Principles and methods. $6^{\text {thedition. }}$ Philadelphia: Lippincott.

Raudenbush, S. W., \& Bhumirat, C. (1992). The distribution of resources for primary education and its consequences for educational achievement in Thailand. International Journal of Educational Research, 17(2), 143-164.

Rohman, A. (2019). Elementary School Teacher Development Policy in Yogyakarta City. International Journal of Learning, Teaching and Educational Research, 18(6), 236-246. https://doi.org/10.26803/ijlter.18.6.14

Shaleh, A. F. (2018). Primary Education in Bangladesh: Feasibility of Achieving Sustainable Development Goals. Dhaka: ABOSAR

Solheim, Ksenia (2019). Teachers' Aspirations to Improve their Classroom Interaction. International Journal of Learning, Teaching and Educational Research, 18(6), 147-169

Sonia, Alma et al., (2019). How Well-Protected are Teachers in School? International Journal of Learning, Teaching and Educational Research, 18(6), 201-213. https://doi. org/10.26803/ijlter.18.6.12

Sultana, M., R. (2019). Primary School effectiveness: Conceptualising different Assessment Approaches. Institute of Bangladesh studies Journal, University of Rajshahi, 20, 32-46.

The World Bank. (1999).Education Sector Strategy., Washington, D.C: The IBRD.

UNESCO. (2004). Education for all: the quality imperative. (EFA global monitoring report 2005). Paris: United Nations Educational, Scientific and Cultural Organization.

UNICEF. (2000). . A paper presented by UNICEF at the meeting of the international working group on education. Florence. Italy.

Ushadevi, M. D. (2001). External Supervision Support for Enhancing Quality in Primary Education. (Working paper 86). Bangalore: The Institute for Social and Economic Change. 